\title{
Determination of pentachlorophenol in wastewater irrigated soils and incubated earthworms
}

\author{
Ying Liu, Bei Wen, Xiao-quan Shan* \\ State Key Laboratory of Environmental Chemistry and Ecotoxicology, Research Center for Eco-Environmental Sciences, \\ Chinese Academy of Sciences, P.O. Box 2871, Beijing 100085, China \\ Received 17 October 2005; received in revised form 28 December 2005; accepted 28 December 2005 \\ Available online 21 February 2006
}

\begin{abstract}
The analyses of low pentachlorophenol (PCP) in soils and earthworms require a sensitive and reliable analytical method. In this paper, several derivatization methods and extraction solvents were compared systematically. The derivatization reagents included acetic anhydride, 2,3,4,5,6pentafluorobenzyl bromide (PFBBr) and diazomethane. Hexane, acetone, hexane-acetone (1:1), dichloromethane and methanol were used as the extraction solvents. PFBBr derivatization showed the highest sensitivity. The derivatization parameters of PFBBr including the amount of PFBBr, the power and irradiation time of microwave were optimized. As a result, $200 \mu \mathrm{l}$ of $\mathrm{PFBBr}(10 \%)$ at $150 \mathrm{~W}$ of microwave oven for 30 min achieved the best result. The PFBBr derivatization method had the detection limit of $0.07 \mu \mathrm{g}^{-1}$ of PCP. Extraction by a mixture of hexane and acetone (1:1) showed the best recoveries. The recommended method was used to determine the low PCP in soils irrigated by wastewater and earthworms incubated in the corresponding soils. The concentrations of PCP in soils were in the range of $1.38-179 \mathrm{ng} \mathrm{g}^{-1}$, while those in earthworms were $11.2-262 \mathrm{ng} \mathrm{g}^{-1}$. The recoveries of the surrogate standard (trichlorophenol) ranged from $81.1 \%$ to $107 \%$, demonstrating the merit of the method. (C) 2006 Published by Elsevier B.V.
\end{abstract}

Keywords: Pentachlorophenol; Derivatization; Extraction; Soils; Earthworms

\section{Introduction}

Pentachlorophenol (PCP) is listed as the 31st most hazardous substance in the US Federal Register of 1991 [1], but has been used worldwide for more than 50 years as a general biocide [2]. Its major application today is in the treatment and preservation of wood products [3]. The widespread use of PCP and its recalcitrant nature results in the global environmental contamination. It has been detected in air, soil, groundwater and surface water near some industrial discharges [4].

Wastewater irrigation is a common practice for agriculture in China as well as in arid and semi-arid areas. Various pollutants could be introduced and accumulated in the soil environment after long-term wastewater irrigation because of mismanagement and improper treatment of wastewater. Much attention has been paid to the accumulation and bio-transfer of heavy metals in the soil system as a consequence of wastewater

\footnotetext{
* Corresponding author. Tel.: +86 1062923560 ; fax: +86 1062923563 .

E-mail address: xiaoquan@ rcees.ac.cn (X.-q. Shan).
}

irrigation [5,6]. However, accumulation of persistent organic pollutants, such as PCP and the associated ecological consequences after wastewater irrigation has not been emphasized sufficiently [7]. Earthworms comprise the largest part of the soil fauna biomass and are able to accumulate various organic contaminants [8,9]. Accumulation of organic contaminants in earthworms implies a risk not only for the earthworm population itself, but also for many vertebrate species feeding on earthworms. Therefore, the quantitative determination of PCP in soil and incubated earthworms is of high interest with regard to soil quality and remediation of contaminated soils. To this end, the accurate determination of low PCP-content is required $[10,11]$.

Many methods have been described for the determination of PCP in the environment [11-20]. As PCP needs to be determined at trace level, the first step of the protocol consists of an extraction procedure. Several extraction techniques have been proposed. Although some assistant methods, such as supercritical fluid [15], sonication [10,16,21,22], and microwave [23] extraction were adopted, Soxhlet extraction is still applied as an effective and economic one $[14,24,25]$. As far as the extrac- 
tion technique is concerned, extraction solvent is a key factor [26]. Among the solvents ethanol [21], dichloromethane [14,25], methanol [27,28], toluene [13,16,17], hexane [10,22], acetone [29] and a mixture of hexane and acetone [25] were frequently used.

GC is a favorite determination technique for organic pollutants. However, some organic compounds, especially chlorophenols, do not have favorable gas chromatographic properties because of their relative polarity, thermal instability and low volatility, thereby causing adsorption and tailing of chromatographic peaks [30]. These shortcomings can be overcome to a large extent by derivatization, such as methylation [12,30], pentafluorobenzylation [31,32] and acetylation [10,13,33]. However, different detection limits are reported by different analysts even the same derivatization method was used. For example, the detection limits of PFBBr derivatization were described to be $1-4 \mu \mathrm{gl}^{-1}$ [31], $10 \mu \mathrm{g} \mathrm{l}^{-1}$ [34], and $100 \mu \mathrm{gl}^{-1}$ [35]. Thus, it is important to make overall comparison of different derivatization methods.

The aim of this study is to compare different derivatization procedures and extraction solvents in detail, thus to establish a suitable routine GC-ECD method for the sensitive determination of low PCP content in wastewater irrigated soils and earthworms; it is significant to assess environmental risk of wastewater irrigated soil.

\section{Materials and methods}

\subsection{Sample collection and earthworm incubation}

\subsubsection{Soil sample collection}

Soil samples were collected from 10 sites in a representative wastewater irrigated farmland downstream in the suburb of Beijing, China. The sampling sites were allocated along the irrigation channels. The wastewater consists of effluents from the sewage plant and untreated wastewater from a coal plant. At each site, four cores of the topsoil at the depth of $10 \mathrm{~cm}$ were taken at random and pooled together in the field. All soil samples were air-dried, ground and screened through a 2-mm stainless sieve to remove stones, plant roots and other large particles.

\subsubsection{Earthworm incubation}

Fifteen clitellate earthworms (Eisenia fetida), average $0.3 \mathrm{~g}$ of each, were kept in uncontaminated background soil for 1 week before being introduced to $1 \mathrm{~kg}$ moistened wastewater irrigated soils ( $40 \%$ on water-holding capacity). Five soils were selected randomly from 10 soil samples for this purpose. Each soil has triplicate experiments. The beakers covered with wet filter paper were kept in the dark at $22 \pm 2{ }^{\circ} \mathrm{C}$ and de-ionized water was added daily to compensate for water loss due to evapotranspiration during the incubation. After 15 days, the earthworms were removed, rinsed with water, and kept in wet filter paper for $24 \mathrm{~h}$ to allow the gut to empty. Then the earthworms were rinsed with water again and stored at $-20{ }^{\circ} \mathrm{C}$ prior to the determination of PCP.

\subsection{Apparatus}

Gas chromatograph, equipped with a ${ }^{63} \mathrm{Ni}$ electron capture detector (GC-ECD) (Hewlett Packard 6890, USA) and a HP5 fused silica capillary column (film $0.32 \mu \mathrm{m}$, i.d. $0.25 \mathrm{~mm}$, length $30 \mathrm{~m}$ ) (J\&W, USA), was used for PCP determination. Chromatographic data were collected and recorded using a HP Chemstation. A home microwave oven (Midea, PJ21C$\mathrm{BI}, 800 \mathrm{~W}$, China) was used in the PCP derivatization by PFBBr.

\subsection{Reagents and standards}

All the organic solvents were commercial available. Dichloromethane, methanol, $n$-hexane (Mallinckrodt, USA), and acetone (Merck, USA) were of pesticide grade. Acetic anhydride (Merck, USA), 2,3,4,5,6-pentafluorobenzyl bromide (Acros, NJ, USA) and anhydrous potassium carbonate (Beijing Chemicals, China) were of analytical grade. Anhydrous sodium sulphate (pesticide grade, Merck, China) was heated at $130{ }^{\circ} \mathrm{C}$ for $24 \mathrm{~h}$ before use.

Reference standards of PCP (AccuStandard Inc., New Haven, USA), internal standard 2,4,6-tribromophenol (AccuStandard Inc., New Haven, USA) and surrogate standard 2,4,6-trichlorophenol (AccuStandard Inc., New Haven, USA) were made in $n$-hexane, stored in sealed containers and preserved in $4^{\circ} \mathrm{C}$. The containers were weighed and the volatile solvents were compensated before use. Working solutions were prepared by diluting stock solutions in derivatization medium.

\subsection{Comparison of three derivatization methods}

\subsubsection{Methylation using diazomethane solution}

PCP was derived according to the method of Zuin et al. [12]. Briefly, $1 \mathrm{ml}$ of a diazomethane solution (freshly prepared by distillation of $2.14 \mathrm{~g} \mathrm{~N}$-methyl- $N$-nitroso- $p$-toluenesulfonamide with $10 \mathrm{ml} \mathrm{KOH} 96 \%$ in ethanol and $30 \mathrm{ml}$ ethyl ether) was added to $1 \mathrm{ml}$ standard solution. Then, the yellow mixture remained at room temperature for about $60 \mathrm{~min}$ for a complete methylation. The volume was reduced to $1 \mathrm{ml}$ by evaporation under a gentle stream of $\mathrm{N}_{2}$.

\subsubsection{Acetylation using acetic anhydride}

The development of this procedure was based on the method of Buhr et al. [13]. Acetic anhydride was used for derivation of PCP to PCP-acetate. Ten milliliters of $0.1 \mathrm{moll}^{-1} \mathrm{~K}_{2} \mathrm{CO}_{3}$ solution were filled in a $20 \mathrm{ml}$ flask, then $1 \mathrm{ml}$ PCP was added. The derivation procedure at room temperature was as follows: stirring for $10 \mathrm{~min}$ - addition of $0.25 \mathrm{ml}$ acetic anhydride - stirring for $10 \mathrm{~min}$ - addition of $0.25 \mathrm{ml}$ acetic anhydride - stirring for $10 \mathrm{~min}$. Then $9 \mathrm{ml}$ hexane was added. The solution was stirred for $10 \mathrm{~min}$ and set for $10 \mathrm{~min}$. The organic phase was separated, dried over $\mathrm{Na}_{2} \mathrm{SO}_{4}$ for $5 \mathrm{~min}$. Then, $5 \mathrm{ml}$ of organic phase was removed and reduced to $0.5 \mathrm{ml}$ by evaporation under a gentle stream of $\mathrm{N}_{2}$. 

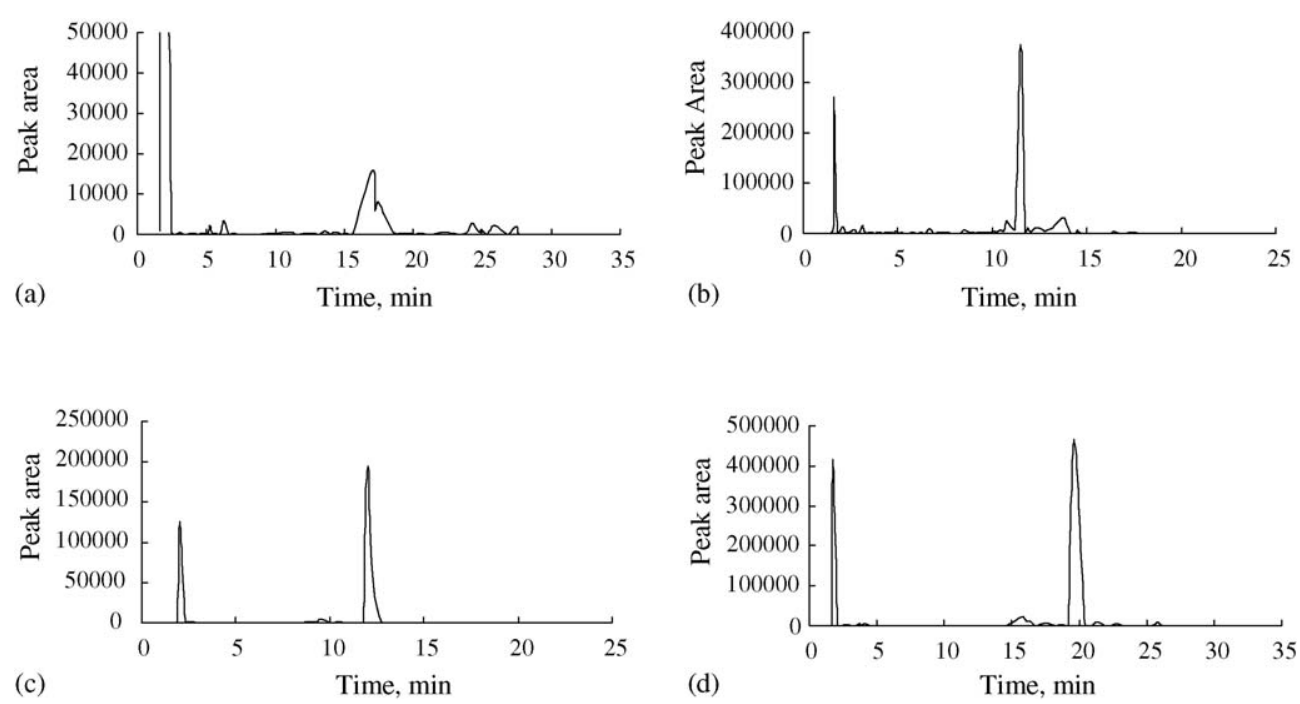

Fig. 1. Comparison of chromatograms of PCP with and without derivatization using different derivatization reagents, $\mathrm{PCP}$ concentration was set at $1 \mu \mathrm{g} \mathrm{ml}^{-1}$ : (a) without derivatization, retention time: $17.03 \mathrm{~min}$; (b) diazomethane, retention time: $11.47 \mathrm{~min}$; (c) HAc, retention time: $12.01 \mathrm{~min}$; (d) PFBBr, retention time: $19.65 \mathrm{~min}$.

\subsubsection{Pentafluorobenzylation using $P F B B r$}

The experimental conditions of $\mathrm{Fu}$ and $\mathrm{Xu}$ [35] were followed. Briefly, $5 \mathrm{ml}$ acetone, $0.1 \mathrm{~g} \mathrm{~K}_{2} \mathrm{CO}_{3}$, and $0.5 \mathrm{~g} \mathrm{Na}_{2} \mathrm{SO}_{4}$ were added into $10 \mathrm{ml}$ flask, together with $1 \mathrm{ml} \mathrm{PCP}$ standard solution. After stirring vigorously for thoroughly intermixing, $100 \mu 110 \%$ PFBBr was added. Then the flask was stirred vigorously again, sealed well, placed in a microwave oven, and derivatized at $150 \mathrm{~W}$ for $4 \mathrm{~min}$. After cooled down, removed from the flask to a concentrator, washed with $5 \mathrm{ml}$ acetone three times, the organic phase was reduced to $1 \mathrm{ml}$ by evaporation under a gentle stream of $\mathrm{N}_{2}$.

\subsubsection{Gas chromatographic analysis and calibration}

One microliter of the solution containing PCP derivative was injected into a split/splitless injector (splitless mode). For determination of derivatized PCP by acetic anhydride and diazomethane, the injector temperature was set at $250^{\circ} \mathrm{C}$; detector temperature was $300^{\circ} \mathrm{C}$; the initial column temperature was $55^{\circ} \mathrm{C}$, programmed at $55^{\circ} \mathrm{C}$ for $1.75 \mathrm{~min}$, then from 55 to $280^{\circ} \mathrm{C}$ at $20^{\circ} \mathrm{C} \mathrm{min}^{-1}$, and maintained at this temperature for $8 \mathrm{~min}$. The total analytical time was $21 \mathrm{~min}$. For determination of derivatized $\mathrm{PCP}$ by $\mathrm{PFBBr}$, the injector temperature was $250^{\circ} \mathrm{C}$; the initial column temperature was $55^{\circ} \mathrm{C}$, programmed at $55^{\circ} \mathrm{C}$ for $1.75 \mathrm{~min}$, then from 55 to $230^{\circ} \mathrm{C}$ at $15^{\circ} \mathrm{C} \mathrm{min}{ }^{-1}$, and maintained at this temperature for $5 \mathrm{~min}$, then from 230 to $280^{\circ} \mathrm{C}$ at $5^{\circ} \mathrm{C} \mathrm{min}^{-1}$, and maintained at $280^{\circ} \mathrm{C}$ for $2 \mathrm{~min}$. The detector temperature was $300^{\circ} \mathrm{C}$. The total analytical time was $30.42 \mathrm{~min}$.

Calibration was performed for the concentration range from 5 to $1000 \mathrm{ng} \mathrm{ml}^{-1}$. One hundred nanogram of 2,4,6tribromophenol was used as an internal standard.

\subsection{Analysis of PCP in soil and earthworm samples}

Soxhlet extraction was used in this study. Earthworms were frozen at $-20^{\circ} \mathrm{C}$ and ground with a mortar and pestle. Ten grams of soil or 3-5 g of ground earthworm tissue were mixed with $10 \mathrm{~g}$ anhydrous $\mathrm{Na}_{2} \mathrm{SO}_{4}$ in paper extraction thimbles and then extracted with $100 \mathrm{ml}$ hexane-acetone for $48 \mathrm{~h}$ at 10 min cycle ${ }^{-1}$. The extract was carefully concentrated to $2 \mathrm{ml}$ by rotary evaporator. The residue was transferred to a column $(1 \mathrm{~cm}$ i.d. $\times 5 \mathrm{~cm})$ prepared by packing silica gel $(60-80 \mathrm{mesh})$, covered by a $2 \mathrm{~cm}$ layer of sodium sulfate, and then washed with $30 \mathrm{ml}$ hexane and $30 \mathrm{ml}$ acetone. The eluate was reduced to $1 \mathrm{ml}$ volume for analysis. PCP in the extract was reacted with $200 \mu \mathrm{l}$ $10 \% \mathrm{PFBBr}$ for derivatization. The microwave oven power was set at $150 \mathrm{~W}$, and the reaction time was $30 \mathrm{~min}$. After derivatization, extraction solvent was removed. The residue was washed with $3 \mathrm{ml}$ hexane-acetone (1:1) three times. The liquid was evaporated to $1 \mathrm{ml}$. One microliter of derivatized PCP was injected into GC-ECD for analysis.

To assure quality of the proposed analytical method, the method blank was analyzed in each analytical batch. The blank values of the analytical procedure were determined by extracting an empty cellulose thimble by the same method as the real sample. No chromatographic peak of derivatized PCP was found in chromatograms of the procedural blank. 2,4,6-Trichlorophenol was used as surrogate standard to monitor the performance of the extraction, cleanup, analytical system and the effectiveness of the method, which was added to the samples before Soxhlet extraction. 2,4,6-Tribromohenol added before sample derivatization was used as internal standard to quantitatively evaluate the amounts of PCP.

\section{Results and discussion}

\subsection{Comparison of three derivatization method}

In this study, a systemic comparison was made among acetic anhydride, PFBBr and diazomethane derivatization methods in terms of the peak shape, the linearity of the calibration curves, the detection limit and the stability of the three derivatives. 
Table 1

Regression equation and linear correlation coefficients of three derivatization methods

\begin{tabular}{llll}
\hline Method & $\begin{array}{l}\text { Regression } \\
\text { equation }\end{array}$ & $\begin{array}{l}\text { Correlation } \\
\text { coefficient }\end{array}$ & $\begin{array}{l}\text { Detect limit } \\
\left(\mu \mathrm{g}^{-1}\right)\end{array}$ \\
\hline Methylation & $y=371.27 x$ & $0.998^{*}$ & 0.5 \\
Acetylation & $y=255.07 x$ & $0.999^{*}$ & 0.7 \\
Pentafluorobenzylation & $y=473.71 x$ & $0.999^{*}$ & 0.4
\end{tabular}

* Significant at 0.01 probability level.

\subsubsection{The chromatograms of three derivates}

The gas chromatogram (Fig. 1) demonstrated that after derivatization PCP's unfavorable gas chromatographic properties (Fig. 1a) were overcome, and symmetrical chromatographic peaks were obtained, and the tailing was decreased. Most importantly, the detection limit of PCP in GC was improved effectively.

\subsubsection{Linearity of the calibration curves and the detection limits}

The linearity of the derivatives was compared when diazomethane, acetic anhydride and $\mathrm{PFBBr}$ were used as derivatization reagents. The data points were fitted to a simple straight-line model $y_{i}=a x_{i}$. When the linear two-parameter model, $y_{i}=a x_{i}+b$, was used, the quality of the fit was not significantly improved on a probability level of $99 \%$. As shown in Table 1 , all the three derivatization methods had good linearity, with correlation coefficients greater than 0.998. The linear range of PCP was from 5 to $1000 \mathrm{ng} \mathrm{ml}^{-1}$. Based on the detection limits defined as the signal-to-noise $(S / N)$ ratio of 3 , the PFBBr had the lowest detection limit, while acetylation had the highest (Table 1). The relative standard deviation (R.S.D.) of six measurements was at the range of $1.3-4.8 \%$, respectively.

\subsubsection{Stability of the three derivatives}

In order to examine the stability of acetic anhydride, $\mathrm{PFBBr}$ and diazomethane derivatives, each derivative was injected into GC-ECD repeatedly. The concentration of PCP for this purpose was $100 \mathrm{ng} \mathrm{ml}^{-1}$. The calibration curves were constructed newly everyday. The derivatives were preserved in dark at $4{ }^{\circ} \mathrm{C}$. The $\mathrm{PFBBr}$ derivative was quite stable within 2 days. No distinct decrease was observed for acetic anhydride derivative after 1 day, however, after 2 days, the recovery decreased by $8 \%$. The diazomethane derivative is instable, and the recovery decreased more than $10 \%$ after 2 days.

\subsection{Optimization of the derivatization conditions}

Although in the previous comparison, $\mathrm{PFBBr}$ derivatization method was proven to be effective; still, the PFBBr derivatization was further optimized including amount of PFBBr used, derivation time and microwave power in order to obtain higher sensitivity. The concentration of PCP for this purpose was set at $100 \mathrm{ng} \mathrm{ml}^{-1}$.

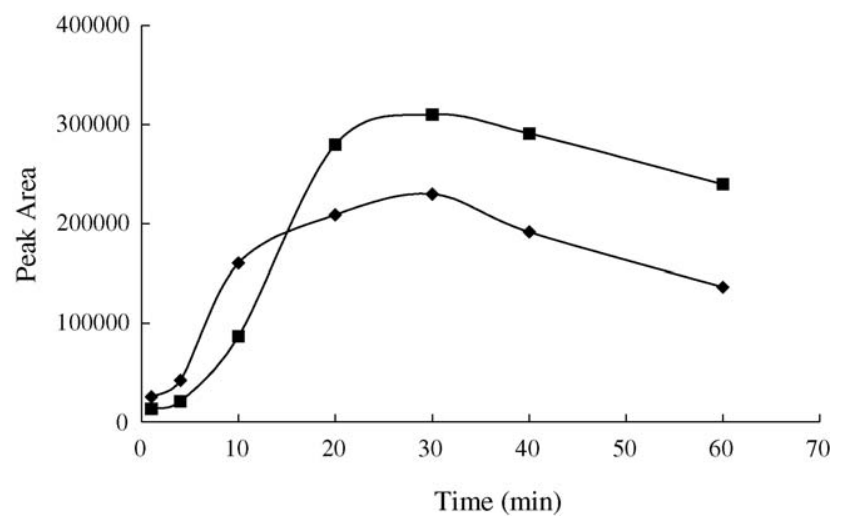

Fig. 2. Effects of PFBBr derivatization time and microwave power on the derivatization efficiency: (ロ) $150 \mathrm{~W}$ and ( $) 300 \mathrm{~W}$.

\subsubsection{Effect of the PFBBr amount on the derivation efficiency}

Fu and $\mathrm{Xu}[35]$ deemed that the volume of $10 \% \mathrm{PFBBr}$ should not exceed $100 \mu \mathrm{l}$, otherwise, more PFBBr could lead to the contamination of GC-ECD. However, the volume of PFBBr recommended by USEPA [32] was $250 \mu$ l. Therefore, the effect of $10 \%$ PFBBr volume on the derivatization efficiency was studied from 50 to $250 \mu \mathrm{l}$. When the volume of PFBBr solution increased, from 50 to $150 \mu$ l, the peak area of PCP derivatives increased obviously. The peak area of $150 \mu l$ was four times larger than that of $50 \mu \mathrm{l}$. When the volume was further increased from 150 to $250 \mu$ l, the peak area remained almost the same. In addition, no contamination of GC-ECD was observed. Thus, $200 \mu 110 \%$ PFBBr was used in the following study.

\subsubsection{Effect of the microwave oven power and reaction time on the derivation efficiency}

A $150 \mathrm{~W}$ microwave oven power and 4 min reaction time were recommended by $\mathrm{Fu}$ and $\mathrm{Xu}$ [35] for $\mathrm{PFBBr}$ derivatization. They found that higher microwave oven power and longer reaction time could sacrifice the recovery. In this study, the effect of microwave oven power and reaction time were reevaluated. As shown in Fig. 2, the peak area of PFBBr derivative obtained at $150 \mathrm{~W}$ microwave oven power was higher than that at $300 \mathrm{~W}$. Under the condition of microwave oven power of $150 \mathrm{~W}$, the peak area increased with the reaction time increased from 1 to $20 \mathrm{~min}$, and maintained unchanged from 20 to $40 \mathrm{~min}$. After that it dropped down when the reaction time was further increased to $60 \mathrm{~min}$. Therefore, the microwave oven power and reaction time were set at $150 \mathrm{~W}$ and $30 \mathrm{~min}$ in the remaining experiment.

The determination sensitivity of PCP was increased greatly under the optimized conditions. The detection limit of $0.07 \mu \mathrm{g} 1^{-1}$ was obtained by the present study, which is much lower than Gurka et al.'s $\left(10 \mu g 1^{-1}\right)$ [34], Boucharat et al.'s $\left(1-4 \mu \mathrm{gl}^{-1}\right)$ [31], and Fu and Xu's $\left(1 \mu \mathrm{g} 1^{-1}\right)$ [35].

\subsection{Comparison of the extraction solvents}

The effects of various extraction solvents, such as hexane, dichloromethane, methanol, acetone and the mixture of hexane and acetone were evaluated for the extraction of PCP from the 


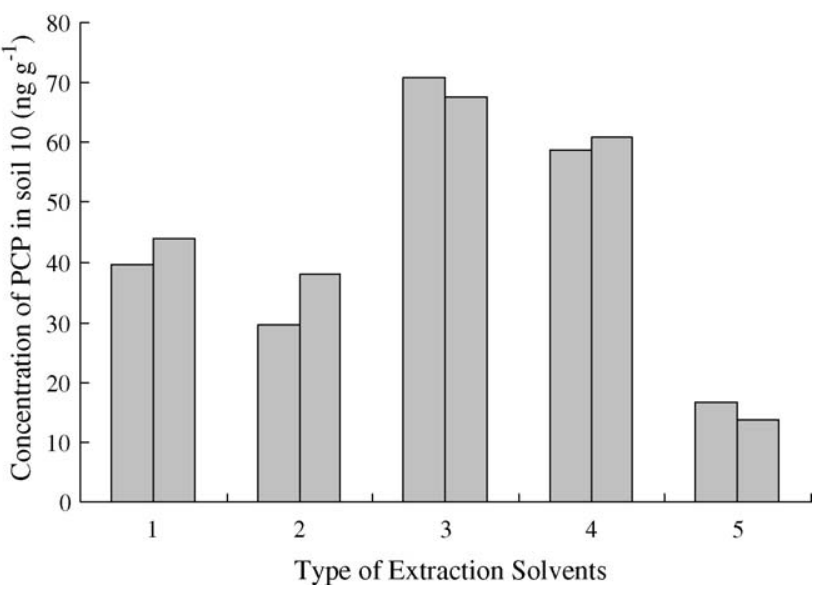

Fig. 3. Effect of different extraction solvents on the extraction efficiency of PCP from soils: (1) hexane; (2) acetone; (3) hexane and acetone (1:1); (4) dichloromethane; (5) methanol.

soil samples before PFBBr derivatization. As shown in Fig. 3 , the highest concentration was obtained when the mixture of hexane and acetone was used as extraction solvent, while low extraction efficiencies were obtained when hexane, dichloromethane, acetone were used separately. Our results were supported by Polese and Ribeiro [10], who compared the extraction ability of PCP from soils between hexane and hexane-acetone (1:1), and found that better recoveries were obtained when hexane-acetone (1:1) was applied as extraction solvent. Although methanol was reported as the best solvent to extract PCP in wood [13], however, the lowest peak area was obtained when methanol was used in this study.

\subsection{Determination of PCP in soil and earthworm samples}

The determination of PCP in soils irrigated by wastewater and earthworms incubated is given in Table 2. The PCP concentrations in soils and earthworms were in the range of 1.38-179 and $11.2-262 \mathrm{ng} \mathrm{g}^{-1}$, respectively. The recoveries of the surrogate standards were at the range of $81-107 \%$, showing sufficient reliability and validity of the method.

So far, there is no Chinese soil quality criterion of PCP available. According to the EPA of Denmark [36], the soil quality criterion of PCP is $150 \mathrm{ng} \mathrm{g}^{-1}$, while the eco-toxicological soil

Table 2

Concentration of PCP in soils and earthworms $(n=6)$

\begin{tabular}{rlccc}
\hline Soil & $\begin{array}{l}\text { PCP in soils } \\
\left(\mathrm{ng} \mathrm{g}^{-1}\right)\end{array}$ & $\begin{array}{l}\text { TCP recovery } \\
(\%)\end{array}$ & $\begin{array}{l}\text { PCP in earthworms } \\
\left(\mathrm{ng} \mathrm{g}^{-1}\right)\end{array}$ & $\begin{array}{l}\text { TCP recovery } \\
(\%)\end{array}$ \\
\hline 1 & $5.53 \pm 0.23$ & 85.6 & - & - \\
2 & $32.9 \pm 1.2$ & 92.0 & $71.6 \pm 6.5$ & 82.3 \\
3 & $1.38 \pm 0.12$ & 81.1 & - & - \\
4 & $18.9 \pm 0.09$ & 89.9 & $47.6 \pm 2.6$ & 92.0 \\
5 & $6.46 \pm 0.20$ & 89.6 & - & - \\
6 & $8.54 \pm 0.06$ & 87.0 & - & - \\
7 & $179 \pm 8$ & 90.6 & $262 \pm 14$ & 84.1 \\
8 & $4.02 \pm 0.24$ & 85.2 & $11.2 \pm 1.1$ & 89.9 \\
9 & $20.2 \pm 1.5$ & 107 & $57.3 \pm 3.0$ & 102 \\
10 & $70.8 \pm 4.0$ & 90.4 & $182 \pm 16$ & 87.0 \\
\hline
\end{tabular}

quality criterion of PCP is $50 \mathrm{ng} \mathrm{g}^{-1}$. Among the 10 soils we determined, the PCP concentrations in soil 7 and 10 were higher than the eco-toxicological soil quality criterion. Moreover, the concentrations of PCP in all earthworms were higher than those in the corresponding soils, indicating the accumulation of PCP in earthworms and the high risk of wastewater irrigation.

\section{Conclusion}

Three derivatization procedures and various extraction solvents were compared and optimized in order to search for the best method for analysis of low-content PCP in soils irrigated with wastewater and earthworms incubated. The PFBBr derivatization and hexane-acetone extraction method revealed lower detection limit, higher reproducibility and better recovery, thus making the determination of PCP in soils and earthworms at nanograms per gram levels feasible. The accumulation of PCP in soils and earthworms were found, which showed that the wastewater irrigated area presented a critical situation, offering risks to different environmental compartments and local population.

\section{Acknowledgement}

This study was supported by the National Natural Science Foundation of China (Grant Numbers: 20377048, 220237010).

\section{References}

[1] Anonymous, US Environmental Protection Agency-synthetic organic chemicals and inorganic chemicals: monitoring for unregulated contaminants, Fed. Reg. 56 (1991) 3526.

[2] S.A. Boyd, M.D. Mikesell, J.F. Lee, in: B.L. Sawhney, K. Brown (Eds.), Chlorophenols in Soils, Soil Science Society of America, Madison, WI, 1989, p. 209.

[3] V.H. Kitunen, R.J. Valo, M.S. Salkinoja-Salonen, Environ. Sci. Technol. 21 (1987) 96.

[4] S.R. Wild, S.J. Harrad, K.C. Jones, Chemosphere 24 (1992) 833.

[5] S. Barbagallo, G.L. Cirelli, S. Indelicato, Water Sci. Technol. 43 (2001) 43.

[6] B. Vedry, M. Gousailles, M. Affholde, Water Sci. Technol. 43 (2001) 101.

[7] Y. Chen, C.X. Wang, Z.J. Wang, S.B. Huang, Plant Soil 261 (2004) 189.

[8] D.E. Morrison, B.K. Robertson, M. Alexander, Environ. Sci. Technol. 34 (2000) 709.

[9] M. Krauss, W. Wilcke, W. Zech, Environ. Sci. Technol. 34 (2000) 4335.

[10] L. Polese, M.L. Ribeiro, Talanta 46 (1998) 915.

[11] M.N. Abbas, G.A.E. Mostafa, A.M.A. Homoda, Talanta 55 (2001) 647.

[12] V.G. Zuin, F.P.S. Airoldi, N.R. Nascimento, M.D. Landgraf, M.O.O. Rezende, J. Braz. Chem. Soc. 10 (1999) 25.

[13] A. Buhr, C. Genning, T. Salthammer, J. Fresenius, Anal. Chem. 367 (2000) 73.

[14] I.H.H. Murald, T. Kazuhiko, F. Shin-Ichiro, Anal. Sci. 17 (2001) 1225.

[15] Y.G. Leblanc, R. Gilbert, J. Hubert, Anal. Chem. 71 (1999) 78.

[16] R. Becker, H. Buge, T. Win, Chemosphere 47 (2002) 1001.

[17] S. Insa, V. Salvado, E. Antico, J. Chromatogr. A 1047 (2004) 15.

[18] V. Pino, F.J. Conde, J.H. Ayaly, A.M. Afonso, V. Gonzalez, J. Chromatogr. A 1099 (2005) 64.

[19] M.C. Wei, J.F. Jen, J. Chromatogr. A 1012 (2003) 111. 
[20] M. Portillo, N. Prohibas, V. Salvado, B.M. Simonet, J. Chromatogr. A 1103 (2006) 29.

[21] A.P. Khodadoust, M.T. Suidan, C.M. Acheson, Chemosphere 38 (1999) 2681.

[22] H.Y. Shen, Talanta 66 (2005) 734.

[23] Y.Y. Shu, T.L. Lai, H. Lin, Chemosphere 52 (2003) 1667.

[24] M.I.H. Helaleh, K. Tanaka, S. Fujii, Anal. Sci. 17 (2001) 1225.

[25] Y.H. Lang, Z.M. Cao, X. Jiang, Talanta 66 (2005) 249.

[26] W.C. Anderson, Solvent/Chemical Extraction Innovative Site Remediation Technology, vol. 5, American Academy of Environmental Engineers, Annapolis, Maryland, 1995, p. 5.

[27] N. Campillo, P. Viñas, I. López-García, N. Aguinaga, M. HernándezCórdoba, Talanta 64 (2004) 584.

[28] N.P. Cassells, C.S. Lane, M. Depala, M. Saeed, D.H. Craston, Chemosphere 40 (2000) 609.
[29] C.A. Peters, R.G. Luthy, Proceedings of the 64th Annual Conference of the Water Pollution Control Federation, Toronto, Canada, 1991.

[30] J. Hajslova, W.H. Tahtah, Z. Jelickova, Sci. Total Environ. 132 (1993).

[31] C. Boucharat, V. Desauziers, P.L. Cloirec, Talanta 47 (1998) 311.

[32] Anonymous, US Environmental Protection Agency. Method 8041Phenols by Gas Chromatography, December, 1996.

[33] M. Ojala, R.A. Ketola, V. Virkki, H. Sorsa, T. Kotiaho, Talanta 44 (1997) 1253.

[34] D.F. Gurka, F.L. Shore, S.T. Pan, J. Assoc. Off. Anal. Chem. 669 (1986) 970.

[35] D.F. Fu, Y.Q. Xu, Crim. Technol. 6 (2002) 15.

[36] Anonymous, Denmark Environmental Protection Agency-Guidelines on Remediation of Contaminated Sites, Environmental Guidelines No. 7, 2002. 